BIORHEOLOGY, 26; 1087, 1989

$0006-355 \mathrm{X} / 89 \$ 3.00+.00$ Printed in the USA.

Copyright (c) 1989 Pergamon Press plc. All rights reserved.

\title{
CONTENTS OF CLINICAL HEMORHEOLOGY, VOLUME 9, NUMBER 5
}

VOLUME 9, NUMBER 5

SPECIAL ISSUE

RED CELL AGGREGATION

Proceedings of the Second International Symposium

Paris, France, January 1988

J.F. Stoltz

J. Janzen and D.E. Brooks

M. Donner, P. Mills and J.F. Stoltz

S.O. Sowemimo-Coker, P. Whittingstall, L. Pietsch, R.M. Bauersachs, R.B. Wenby and H.J. Meiselman

B. Pignon, S. Muller, D. Jolly, M. Siadat,

E. Petitfrere, B. Vessel, M. Donner,

G. Potron and J.F. Stoltz

P. Teitel

M. Boynard and J.C. LeLievre

D. Quemada

D.E. McMillan

J. Dufaux, J.J. Durussel and A. Othmane

\section{A.L. Copley and R.G. King}

A. Clivati, G. Ricciardi, R. Agosti, M. D'Ettorre, L. Pagliano and E. Longhini

S. Witte and I. Anadere

A. Sarno, A. Serra and G. Caimi

C. Le Dévéhat, M. Vimeux, G. Bondoux and A. Bertrand

J.L. Wautier, M.P. Wautier and

P.J. Guillausseau

C. Le Dévéhat, M. Boisseau, M. Vimeux, G. Bondoux and A. Bertrand

M.R. Boisseau, G. Freyburger, M. Busquet and C. Beylot

F. Schooneman, M. Donner, F. Streiff and J.F. Stoltz

J.F. Stoltz

\section{CONTENTS}

693 Red Blood Cell Aggregation: Foreword Papers

695 Do plasma proteins adsorb to red cells?

715 Influence of plasma proteins on erythrocyte aggregation

723 Effects of cellular factors on the aggregation behavior of human, rat and bovine erythrocytes

739 Validation of a method for erythrocyte aggregation measurement using light back-scattering

751 Polymicroviscometry (PMV) and erythrocyte aggregation

771 An approach of red blood cell aggregation by ultrasonic echography

781 Viscometric quantification of erythrocyte aggregation

791 The energy cost of erythrocyte aggregation propensity during normal blood flow

797 In vitro and in vivo study of the role of red blood cell aggregation in capillary flow - Pharmacology applications

809 Erythrocyte aggregation, compaction stasis, the Cohnheim compaction phenomenon and inflammation

823 Erythrocyte aggregation in the newborn: Physiopathological and clinical aspects

831 Modifications of viscoelastic properties during cardiovascular diseases

839 Red cell membrane fluidity and red cell aggregation in vascular atherosclerotic disease

845 Red blood cell aggregation and disaggregation in diabetes mellitus

855 Pharmacological modulation of erythrocyte adhesion to endothelium in diabetes mellitus

861 Hemorheological factors in the pathophysiology of venous disease

871 Pharmacological aspects of erythrocyte aggregation, effect of high doses of troxerutine

877 Erythrocyte aggregation during dysglobulinemia (Preliminary results)

883 Erythrocyte aggregation: Summary, conclusions and prospects

I Software Survey Section

1087 